\title{
METHODOLOGY
}

\section{Identification of proliferating cells in chicken embryos using 5-bromo- 2'-deoxyuridine immunohistochemical detection}

\author{
Mário Lúcio Lopes ${ }^{1}$, Gilberto Silber Schmidt ${ }^{2}$ and Luiz Lehmann Coutinho ${ }^{I}$
}

\begin{abstract}
Chicken embryos were incubated with BrdU, embedded in plastic resin, sectioned and screened immunohistochemically to identify proliferating cells in the neural tube and somites. Fixation in $4 \%$ paraformaldehyde for $1 \mathrm{~h}$ was essential for detecting specific colorimetric signals of BrdU incorporation into cells during the $S$ phase of the cell cycle. Transverse sections of the neural tube showed that the nuclei of proliferating cells (BrdU positive) had a uniform and centralized distribution, whereas unstained nuclei were found only along the extremitie s of the neural tube. Transverse sections of differentiated somites showed proliferating cells in the scleratome and dermatome. However, no incorporation of BrdU was observed in myotomic cells, which give rise to axial skeletal muscle. In spite of their proximity, the dermatome and myotome showed marked differences in cell proliferation. The excellent preservation of morphological characteristics in the embryonic tissues facilitated identification of variations in BrdU incorporation.
\end{abstract}

\section{INTRODUCTION}

Studies of cell proliferation are important for understanding the biological processes involved in the formation and development of multicellular organisms. Traditionally, the techniques used to measure DNA synthesis or cell proliferation were based on ${ }^{3} \mathrm{H}$-thymidine incorporation into cells, tissues and organs (Taylor et al., 1957), with the radioactivity incorporated being detected by autoradiography, fluorography or liquid scintillation. However, the long time required by these procedures and the need to use potentially dangerous and expensive materials have led to the development of non-radioactive methods.

One such non-radioactive approach is based on the use of 5-bromo-2'-deoxyuridine (BrdU). This thymidine analog is incorporated into DNA during the $S$ phase of the cell cycle and is detected in histological sections using antibodies conjugated to enzymes or fluorescent dyes (Gratzner, 1982; Schutte et al., 1987; Mozdziak et al., 1994). Monoclonal antibodies against BrdU react with low affinity (Ka about $10^{-6} \mathrm{M}$ ) and only to single strands of DNA (Kitchin and Brown, 1995). Therefore, BrdU detection depends on avoiding conditions that may interfere with the antigen-antibody interaction.

Most procedures for immunohistochemical analysis are based on paraffin infiltration into biological material or cryostatic sectioning. Immunohistochemical localization of cellular components depends on adequate tissue preservation with no destruction of antigenic sites, and on the acquisition of sufficiently thin sections that provide a good resolution of subcellular structures (Kimberly and Slpecky, 1995). Materials embedded in paraffin are generally well preserved, but the need for relatively thick sections makes high resolution analysis difficult. Furthermore, excessive exposure to organic solvents and high temperatures during infiltration can compromise the intactness of antigenic sites. In contrast, cryostatic sectioning of biological material is done at low temperatures with no need of exposure to organic solvents. Unfortunately, the sections are also thick, and cells can be damaged during freezing, resulting in injury to subcellular components and lower resolution of the final signal. These negative effects are particularly important in delicate embryonic tissues.

An alternative to the above procedures, which provides excellent preservation of the cellular morphology and antigens in delicate tissues, is the use of methacrylate-based plastic resins (Cole and Sykes, 1974). The use of these resins in immunohistochemistry depends on exposure of the antigenic site and on the antibody's capacity to penetrate through the pores formed during polymerization of the resin. Plastic resins have been used successfully in histological studies in adult animals, but few investigations have examined their usefulness in embryonic tissue.

This paper describes the immunohistochemical detection of proliferating cells in high quality histological sections obtained from the neural tube and somites of chicken embryos embedded in plastic resin. 
MATERIAL AND METHODS

Incorporation of BrdU into chicken embryo DNA

Chicken embryos were collected after incubation for $56 \mathrm{~h}$ at $37^{\circ} \mathrm{C}$ and were maintained at this temperature in PBS solution $\left(0.14 \mathrm{M} \mathrm{NaCl}, 2.7 \mathrm{mM} \mathrm{KCl}, 10 \mathrm{mM} \mathrm{Na}_{2} \mathrm{HPO}_{4}\right.$ and $1.8 \mathrm{mM} \mathrm{KH}_{2} \mathrm{PO}_{4}, \mathrm{pH} 7.4$ ) containing $100 \mu \mathrm{mol}$ of BrdU (Boehringer Mannheim). The embryos were subsequently washed twice in PBS (15 min each) to remove excess BrdU and then fixed in PBS with 4\% paraformaldehyde for $1 \mathrm{~h}$ at $4^{\circ} \mathrm{C}$, dehydrated in alcohol $(25,50,70,90$ and $100 \%$ ethanol, 5 min each) and embedded in JB- $4^{\mathrm{TM}}$ plastic resin (Polysciences).

\section{Preparation of embryos for sectioning}

Embryos were transferred to a microcentrifuge tube containing $750 \mu \mathrm{l}$ of $100 \%$ ethanol and $750 \mu \mathrm{l}$ of JB- $4^{\mathrm{TM}}$ resin A with $0.5 \%$ catalyzer. After mixing for $60 \mathrm{~min}$ at $4^{\circ} \mathrm{C}$, the solution was removed and $1,500 \mu \mathrm{l}$ of resin then added. Incubation was continued for $48 \mathrm{~h}$ at $4^{\circ} \mathrm{C}$ with eight changes every $2 \mathrm{~h}$, and two more changes after $16 \mathrm{~h}$ each. Blocks were prepared in a plastic mold with polymerizing agent (Polysciences) at a ratio of 25:1 (JB-4 ${ }^{\mathrm{TM}}$ Sol A: polymerizing agent) followed by $60 \mathrm{~min}$ for polymerizing at room temperature. Five- to six- $\mu \mathrm{m}$ sections were cut with a steel blade. BrdU was detected after transferring the sections to glass slides, followed by drying at $37^{\circ} \mathrm{C}$.

\section{BrdU detection}

The sections were hydrated with PBT-01 (PBS plus $0.1 \%$ Triton X-100) for $5 \mathrm{~min}$ at room temperature. Excess protein was removed by treatment with pronase $\mathrm{E}(100 \mu \mathrm{g} / \mathrm{ml}$ of PBT) for $60 \mathrm{~min}$ at $37^{\circ} \mathrm{C}$, after which the slides were incubated at $65^{\circ} \mathrm{C}$ for $10 \mathrm{~min}$ in a water bath, followed by washing in $30 \mathrm{ml}$ of $0.5 \mathrm{M}$ glycine ( $\mathrm{pH} 2.0$ ) and $20 \mathrm{ml}$ PBT plus $0.1 \mathrm{M}$ glycine (5 min each) at room temperature. After blotting with filter paper, the sections were incubated in $200 \mu \mathrm{l}$ of incubation buffer (Boehringer Mannheim) containing monoclonal mouse antibody against BrdU (diluted 1:10), for $30 \mathrm{~min}$ at $37^{\circ} \mathrm{C}$. The slides were washed twice with $20 \mathrm{ml}$ PBT-01 (10 min each) to remove excess antibodies, incubated for $30 \mathrm{~min}$ at $37^{\circ} \mathrm{C}$ in $200 \mu \mathrm{l}$ of PBT-01 containing polyclonal antibody conjugated with alkaline phosphate $(1 \mathrm{unit} / \mathrm{ml})$ and directed against mouse monoclonal antibody. Following this incubation, the slides were washed twice in $20 \mathrm{ml}$ PBT-01 (10 min each) and once in TSM $(0.1 \mathrm{M}$ Tris- $\mathrm{HCl}, 0.1 \mathrm{M} \mathrm{NaCl}$, $0.05 \mathrm{M} \mathrm{MgCl}_{2}, \mathrm{pH}$ 9.5) for $5 \mathrm{~min}$. Sections were blotted with filter paper before colorimetric detection of BrdU. The substrates used were 5-bromo-4-chloro-3-indoly-1 phosphate plus nitroblue-tetrazolium (BCIP/NBT) at concentrations of $0.17 \mathrm{mg} / \mathrm{ml}$ (BCIP) and $0.33 \mathrm{mg} / \mathrm{ml}$ (NBT) in $200 \mu \mathrm{l}$ of TSM. The sections were developed in a dark room with rapid exposures to light for photomicrography.
Total nucleus detection

Specificity of the signals obtained in the immunohistochemical analyses was confirmed by total nucleus localization, through modification of the procedure described by Goodpasture and Bloom (1975). A 50\% silver nitrate solution was applied to the slides, covered with another slide and kept at room temperature for $20 \mathrm{~min}$. The cover slide was then removed and the sections washed in $25 \mathrm{ml}$ deionized water. The histological sections were stained with 0.2 $\mathrm{MNaOH}$ and monitored by microscopy. When the nucleus turned brown, the reaction was interrupted by two washings in $25 \mathrm{ml}$ of deionized water.

\section{RESULTS AND DISCUSSION}

Immunohistochemical analyses

Proliferating cells that incorporated BrdU were clearly identified by the formation of dark signals in the nucleus (Figure 1). The detection process was quick, simple and did not require special equipment. However, to improve the signal specificity and intensity, it was necessary to reduce the fixation time of the embryos in $4 \%$ paraformaldehyde to $1 \mathrm{~h}$ and to remove excess proteins with pronase $\mathrm{E}$ in order to expose the antigenic sites over the DNA molecules. Washing with Triton X-100 (0.1\%) reduced the background reactions caused by nonspecific absorption of the antibodies without decreasing the sensitivity for BrdU.

According to Schutte et al. (1987), the conditions of fixation can affect the immunoreactivity of the monoclonal antibody towards BrdU-modified DNA, whereas the type of resin can interfere with the antibody's access to antigenic sites. Methacrylate-based plastic resins allow the analysis of delicate embryonic tissues by preserving cytological structures that are important for detecting BrdU incorporation into proliferating cells. The infiltration process, done at $4^{\circ} \mathrm{C}$, was quick and simple, and did not require solvents such as xylene, toluene or benzene. Moreover, 1- and $5-\mu \mathrm{m}$ thick sections were easily obtained with a conventional microtome with a steel blade. The sections had excellent transparency, and the nuclei that incorporated BrdU were easily detected. Staining with silver nitrate identified all the nuclei present in the section.

\section{Identification of proliferating cells in the neural tube}

Immunohistochemical analysis demonstrated that nuclei of proliferating cells in the neural tube were located predominantly in the center of this structure with little reactivity along the outer and inner borders (Figure 1). In contrast, silver staining revealed a uniform distribution of nuclei throughout the entire neural tube (Figure 2). According to Gilbert (1995), the position of the nucleus depends on the cell cycle stage. DNA synthesis initiates when the 


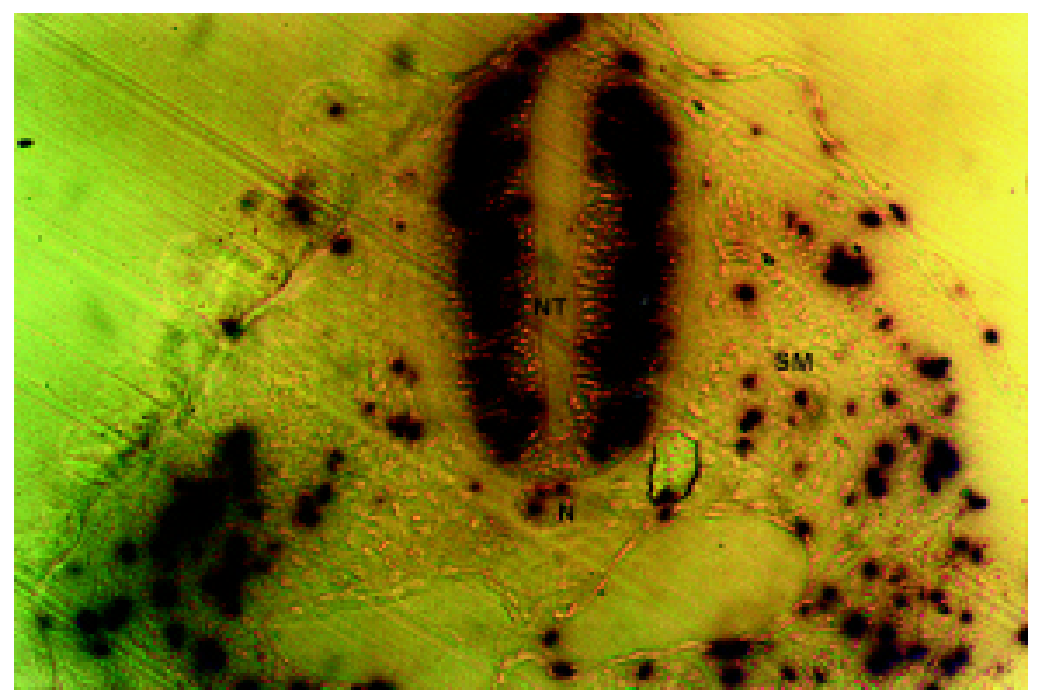

Figure 1 - Transverse section of a chicken embryo (56-h incubation) showing proliferating cells in the neural tube (NT), notochord (N) and somite (SM).

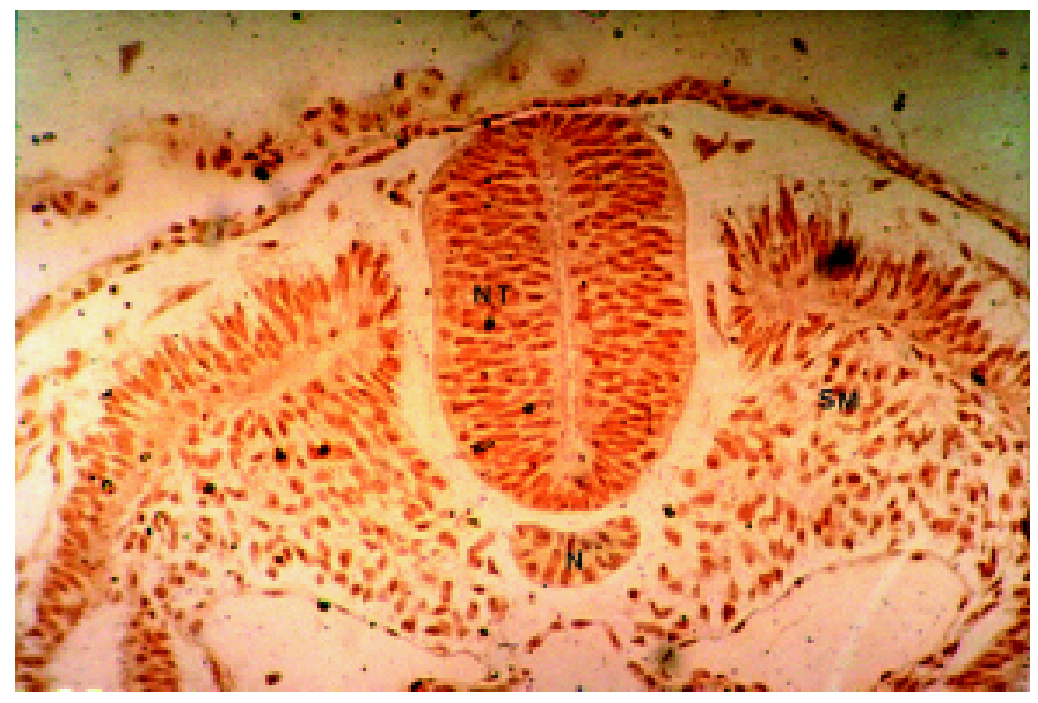

Figure 2 - Transverse section of a chicken embryo (56-h incubation) showing the silver-stained nuclei of cells in the neural tube (NT), notochord $(\mathrm{N})$ and somite (SM).

nucleus is near the outer edge of the neural tube. During the G2 phase, the nuclei migrate towards the neural canal, where cell division occurs, and then return to the outer edge during the G1 phase. The short time allowed for BrdU incorporation $(60 \mathrm{~min})$ meant that the labeled nuclei were concentrated between the two borders of the neural tube, and rarely reached the extremities of the neural canal to initiate mitosis or the G1 phase.

The differences observed in signal intensity were probably related to the period of DNA synthesis during which BrdU was available. Low intensity signals near the neural canal represented nuclei that partially incorporated BrdU in the final $\mathrm{S}$ phase of the cell cycle and migrated a greater distance. On the other hand, nuclei that completed the G1 phase and initiated DNA replication only at the end of the BrdU incubation period developed low intensity signals and remained closer to the outer edge of the neural tube. Proliferating cells that did not reach the $S$ phase, including young glia cells and neurons, did not incorporate BrdU and showed no colorimetric reaction.

Neural tube formation is a very important process, because this structure will subsequently develop into the main regions of the adult animal's brain and spinal medulla (Teillet and LeDouarin, 1983; Rong et al., 1992). The origin of these structures is directly related to cell proliferation and differentiation. According to Fujita (1964), during the initial stages of neural tube formation cells incorporate ${ }^{3} \mathrm{H}$-thymidine into their nuclei, whereas during embryonic 


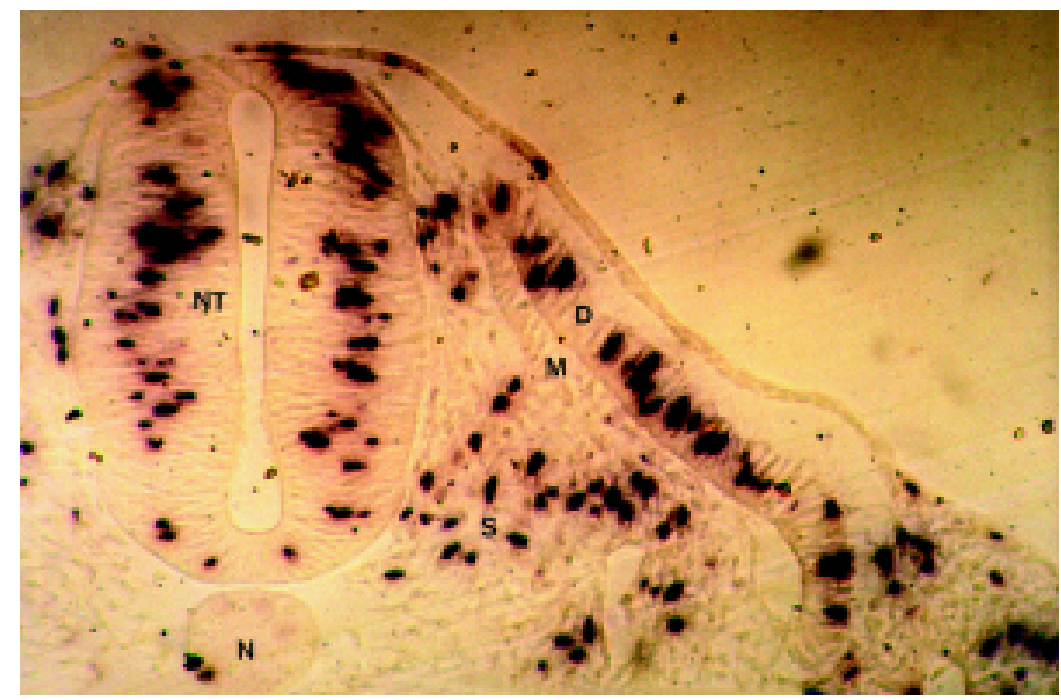

Figure 3 - Transverse section of a chicken embryo (56-h incubation) showing dark-stained BrdU-labeled nuclei of cells in the neural tube (NT), notochord (N), dermatome (D) and scleratome (S). Note the lack of staining in the myotome (M).

development some cells stop incorporating precursors for DNA synthesis because they are no longer involved in active mitosis. Such cells include neurons and glial cells that are differentiated at the extremities of the neural tube.

\section{Identification of proliferating cells in somites}

Somite analysis revealed a high density of proliferating cells in the dermatome, whereas cells in the myotome showed no incorporation of BrdU. Signals were more uniformly distributed in the scleratome, but at a lower density (Figure 3). These results agree with those of Langman and Nelson (1968), based on ${ }^{3} \mathrm{H}$-thymidine incorporation. Using microautoradiography, these authors demonstrated that myotomic cells in chicken embryos did not divide, and that cellular multiplication occurred in the dermatome. According to Philipson and Sorrentino (1992), cells from different tissues, species and embryonic developmental stage have cell cycles that vary considerably in duration. Such variations were evident in transverse sections of somites from embryos exposed to BrdU. Proliferating cells were easily identified in the dermatome and scleratome, but corresponding signals were not observed in the myotome which gives rise to axial skeletal muscle. In spite of their close proximity, the dermatome and myotome exhibited marked differences in cellular proliferation and were easily identified because of the good quality histological sections with wellpreserved morphological characteristics.

In an immunohistochemical analysis done using an antibody against desmin and acetylcholinesterase activity, Kaehn et al. (1988) demonstrated myotome cells in chicken embryos originated from the dermatome, with no contribution from the scleratome. This biological process explains the origin of skeletal muscle in chicken embryos. Our re- sults suggest that dermatome cells proliferate intensively before migrating to the myotome where the cell cycle is interrupted and skeletal muscle gene expression is initiated. The identification of proliferating cells in the somite region thus provides a means for studying the mechanisms involved in muscle fiber formation during the embryonic period.

\section{ACKNOWLEDGMENTS}

This research was supported by grants from the Secretaria de Ciência e Tecnologia do Estado de São Paulo, FAPESP and EMBRAPA. M.L.L. received a DTI scholarship from RHAE-MCT and G.S.S. and L.L.C. are recipients of Research Scholarships from CNPq. Publication supported by FAPESP.

\section{RESUMO}

Embriões de frango foram incubados na presença de BrdU e montados em resina plástica. A detecção de células em proliferação nos somitos e tubo neural foi feita através de anticorpos contra BrdU. Um ponto essencial para a otimização do método foi a fixação dos embriões por apenas uma hora em paraformaldeído a $4 \%$. Análise de cortes transversais revelou que no tubo neural os núcleos marcados se posicionavam na região central. Cortes transversais em somitos diferenciados revelaram a presença de células em proliferação no dermátomo e esclerótomo, no entanto não foi observado nenhum sinal no miótomo. A metodologia aqui apresentada permitiu identificar com clareza e boa resolução as células em proliferação presentes em tecidos embrionários.

\section{REFERENCES}

Cole, M.B. and Sykes, S.M. (1974). Glycol methacrylate in light microscopy: a routine method for embedding and sectioning animal tissues. Stain Technol. 49: 387-400. 
Fujita, S. (1964). Analysis of neuron differentiation in the central nervous system by tritiated thymidine autoradiography. J. Comp. Neurol. 122: 311-328.

Gilbert, S.F. (1995). Início do desenvolvimento em vertebrado: neurulação e ectoderme. In: Biologia do Desenvolvimento. Sociedade Brasileira de Genética, Ribeirão Preto, pp. 267-345.

Goodpasture, C. and Bloom, S.E. (1975). Visualization of nucleolar organizer regions in mammalian chromosomes using silver staining. Chromosoma 53:37-50.

Gratzner, H.G. (1982). Monoclonal antibody to 5-bromo and 5-iododeoxyuridine: a new reagent for detection of DNA replication. Science 218: 474-475.

Kaehn, K., Jacob, H.J., Christ, B., Hinrichsen, K. and Poelmann, R.E. (1988). The onset of myotome formation in the chick. Anat. Embryol. 177: 191201.

Kimberly, A.H. and Slpecky, N.B. (1995). A simplified method for obtaining $0.5 \mathrm{~mm}$ sections of small tissue specimens embedded in PEG. Histochem. Cytochem. 43: 637-643.

Kitchin, K.T. and Brown, J.L. (1995). Incorporation of 5-iodo-2'-deoxyuridine and 5-bromo-2'-deoxyuridine into rodent DNA as determined by neutron activation analysis. Anal. Biochem. 229: 180-187.

Langman, J. and Nelson, G.A. (1968). A radioautographic study of the de- velopment of the somite in the chick embryo. Embryol. Exp. Morphol. 19:217-226.

Mozdziak, P.E., Schultz, E. and Cassens, R.G. (1994). Satellite cell mitosis in posthatch turkey skeletal muscle growth. Poult. Sci. 73: 547-555.

Philipson, L. and Sorrentino, V. (1992). Growth control in animal cells. In Development: The Molecular Genetic Approach (Russo, V.E.A., Brody, S., Cove, D. and Ottolenghi, S., eds.). Springer-Verlag, Berlin, pp. 537553.

Rong, P.M., Teillet, M.A., Ziller, C. and LeDouarin, N.M. (1992). The tube neural/notochord complex is necessary for vertebral but not limb and body wall striated muscle differentiation. Development 115: 657-672.

Schutte, B., Reynders, M.M.J., Bosman, F.T. and Blijham, G.H. (1987). Effect of tissue fixation on anti-bromodeoxyuridine immunohistochemistry. Histochem. Cytochem. 35: 1343-1345.

Taylor, J.H., Woods, P.S. and Hughes, W.L. (1957). The organization and duplication of chromosomes as revealed by autoradiographic studies using tritium-labeled thymidine. Proc. Natl. Acad. Sci. USA 43: 122-127.

Teillet, M.A. and LeDouarin, N.M. (1983). Consequences of neural tube and notochord excision on the development of the peripheral nervous system in the chick embryo. Dev. Biol. 120: 329-347.

(Received September 3, 1998) 
